Article

\title{
Kinetics of Hyaluronidase Inhibition by Rice (Oryza sativa L.) Protein Hydrolysate
}

\author{
Hui-Ju Chen ${ }^{1,2}$, Fan-Jhen Dai ${ }^{2}$, Siao-Ling Fan ${ }^{2}$, Yu-Chun Huang ${ }^{2}$, Chi-Fai Chau ${ }^{1}{ }^{(\mathbb{D} \text {, }}$ \\ Yung-Sheng Lin $3,4, * \mathbb{D}$ and Chin-Shuh Chen ${ }^{1, *}$ \\ 1 Department of Food Science and Biotechnology, National Chung Hsing University, Taichung 402204, Taiwan; \\ d103043004@mail.nchu.edu.tw (H.-J.C.); chaucf@nchu.edu.tw (C.-F.C.) \\ 2 Healthmate Co., Ltd., Changhua City 50056, Taiwan; jane@healthmate.com.tw (F.-J.D.); \\ eileen@healthmate.com.tw (S.-L.F.); tina@healthmate.com.tw (Y.-C.H.) \\ 3 Department of Chemical Engineering, National United University, Miaoli 36063, Taiwan \\ 4 Institute of Food Safety and Health Risk Assessment, National Yang-Ming University, Taipei 11221, Taiwan \\ * Correspondence: linys@nuu.edu.tw (Y.-S.L.); cschen@mail.nchu.edu.tw (C.-S.C.)
}

Received: 27 November 2020; Accepted: 14 December 2020; Published: 18 December 2020

check for updates

\begin{abstract}
Research on the skin's maintenance and protection against aging has gradually progressed toward phytocosmetics. This study investigated the in vitro hyaluronidase inhibitory activity of rice protein hydrolysate obtained by using bacterial amylase and protease against skin aging-related enzymes. Here, the molecular weights of rice protein hydrolysates were in the range 5-63 kDa. Every $100 \mathrm{~g}$ of a rice protein hydrolysate contains approximately $2960 \mathrm{mg}$ of total amino acid, including essential amino acids (893 mg) and branched-chain amino acids (591 mg). A kinetic study showed that hyaluronidase inhibition by the rice protein hydrolysate occurs through a competitive reaction mechanism. Achieving effective hyaluronidase inhibitory activity, the rice protein hydrolysate had a half maximal inhibitory concentration of $7.61 \mathrm{mg} / \mathrm{mL}$. Because hyaluronidase activity inhibition is crucial for treating skin aging, rice protein hydrolysates should be considered as cosmeceutical ingredients.
\end{abstract}

Keywords: rice; protein; hydrolysate; Oryza sativa L.; hyaluronidase

\section{Introduction}

Protein is among the 10 trends that most strongly drive the current functional food market. Protein is an essential amino acid (EAA) source and thus a functional component of health [1]. Enzymatic protein hydrolysis requires mild conditions, elicits few side reactions, and increases the extraction rate, ultimately providing free amino acids and peptides in a variety of sizes. Owing to their functional and nutritional properties, enzymatic protein hydrolysates may have clinical and dietary (e.g., protein supplementation) application [2].

Rice protein hydrolysates and their mixtures used in many studies can be obtained by subjecting flours and protein concentrates or isolates to microbial fermentation or chemical or enzymatic hydrolysis [3]. In the food industry, enzymatic hydrolysis is preferred because during processing, no toxic chemical residues are produced. The sources of proteolytic enzymes include not only animals and plants but also microorganisms. Their varied specificities render each proteolytic enzyme able to cleave proteins at only certain peptide bonds [4]. The sequence and biological properties of the resulting peptides are also affected by other factors, such as protein source and reaction temperature, time, and $\mathrm{pH}$. After the completion of hydrolysis, the subsequent steps applied are ultrafiltration and chromatography-all to obtain peptides or peptide fractions that are highly pure and have distinct molecular weights, hydrophobicities, and ionization states $[5,6]$. Studies [7-9] have 
reported on the biological functions of grain and vegetable protein hydrolysates and derived peptides; the biological functions include antitumor, antithrombotic, antihypertensive, cholesterol-lowering, and antioxidant activities, and the grains and vegetables have included soybeans, corn gluten, rice, rice bran, and potatoes. Being excellent sources of not only proteins but also biologically active substances, plant protein hydrolysates have potential utility as differing providers of protein and beneficial-to-health elements in some nutritional products [10].

Hyaluronic acid (HA) — a glycosaminoglycan with high molecular weight—can increase skin hydration and lubrication and maintain skin plasticity, smoothness, and moistness [11]. Moreover, to obtain skin with high vitality, maintaining the skin's moisture and the stratum corneum's extracellular matrix is crucial. However, in the skin, hyaluronidase constantly breaks down HA to result in drying and eventually sagging of the skin. Youthful skin can be thus achieved by inhibiting hyaluronidase and facilitating the synthesis of matrix proteins [12].

The use of protein hydrolysates from rice-which is the principal food crop for at least $50 \%$ of people globally - as a hyaluronidase inhibitor has not been reported thus far. Therefore, here, a rice protein hydrolysate's utility for hyaluronidase activity inhibition was evaluated, followed by the development of alternative natural cosmetic materials.

\section{Materials and Methods}

\subsection{Rice Protein Hydrolysate Preparation}

We first ground polished rice seeds (Oryza sativa L.), followed by sieving the ground rice through a 40-mesh screen (U.S. Standard sieve) and finally storing it at $0^{\circ} \mathrm{C}$ until use. For experiments, we soaked rice flour $(100 \mathrm{~g})$ in distilled water $(1000 \mathrm{~mL})$ containing $2 \%$ bacterial amylase (Genencor, Palo Alto, CA, USA) and then heated this mixture to $95^{\circ} \mathrm{C}$ for $30 \mathrm{~min}$; finally, it was cooled to room temperature. The supernatant was removed through 10 -min centrifugation at $4000 \mathrm{rpm}$. After adding $0.1 \%$ protease to the insoluble portion, we incubated the solution and applied shaking for $4 \mathrm{~h}$. The enzymatic hydrolysis conditions for protease (Healthmate, Changhua, Taiwan) were a $\mathrm{pH}$ of 8.5 and temperature of $55^{\circ} \mathrm{C}$. The remaining insoluble portion was removed through $15-\mathrm{min}$ centrifugation at $5000 \mathrm{rpm}$, and finally, the supernatant was lyophilized and stored at $-20^{\circ} \mathrm{C}$ (Figure 1).

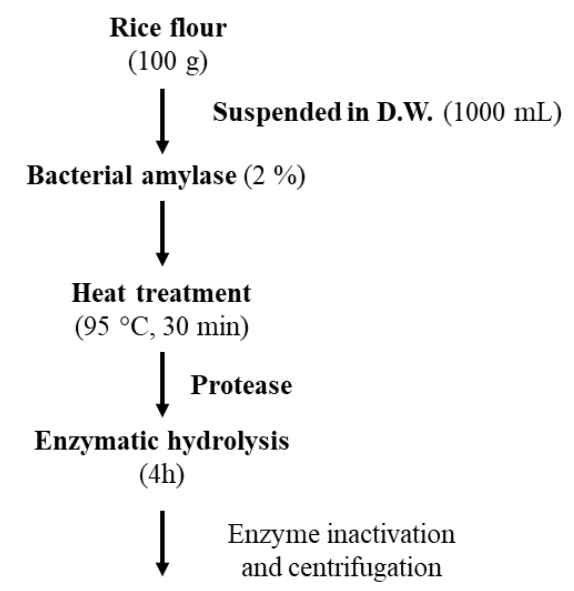

Rice protein hydrolysates

Figure 1. Rice protein hydrolysate preparation flow.

\subsubsection{Gel Electrophoresis for Determination of Protein Molecular Weight}

We employed tricine-sodium dodecyl sulfate (SDS) polyacrylamide gel electrophoresis (PAGE) that was based on Schägger's [13] method. In brief, we prepared a stacking gel (4\% w/v gel) and different resolving gels $(7 \%, 9 \%$, and $10 \% \mathrm{w} / \mathrm{v})$ such that the pore size was smaller in the stacking gel than in the resolving gel. Here, the stacking gel functioned to line up all the test samples loaded on the 
gel such that they simultaneously penetrated the resolving gel, where the proteins separated on the basis of their molecular weights. Freeze-dried protein samples were dispersed in a buffer solution ( 0.375 mol/L Tris-HCl, $30 \mathrm{~g} / \mathrm{L}$ SDS, $75 \mathrm{~g} / \mathrm{L}$ glycerol, and $0.125 \mathrm{~g} / \mathrm{L}$ Coomassie blue G 250, pH 7) and centrifuged before loading. 2-Mercaptoethanol $(20 \mu \mathrm{L})$ was placed in $1 \mathrm{~mL}$ of the prepared sample, which was then incubated for $90 \mathrm{~s}$ in a $100{ }^{\circ} \mathrm{C}$ bath. Thereafter, every sample well was loaded with only one test sample. Next, the electrophoresis was performed at a $30 \mathrm{mV}$ until all test samples were found to have entered the stacking gel, and then the voltage was changed to $100 \mathrm{mV}$ until the end of the experiment. The obtained polypeptide bands were then fixed in a fixing solution for $30 \mathrm{~min}$ and then submerged in a staining solution for $30 \mathrm{~min}$. Finally, the gels were incubated in $10 \%$ acetic acid overnight with shaking for complete destaining of the gel backgrounds.

\subsubsection{Sample Amino Acid Profiles}

In accordance with a previously reported method [14], we employed methanesulfonic acid (4N) at $115^{\circ} \mathrm{C}$ for $24 \mathrm{~h}$ in evacuated tubes to hydrolyze our rice protein samples and then analyzed the resulting hydrolysate for their amino acid profiles on an L-8900 amino acid analyzer (Hitachi, Tokyo, Japan).

\subsection{Hyaluronidase Inhibitory Activity Analysis}

Antihyaluronidase assay was conducted according to a previous method [15]. In brief, we mixed the sample solution, $5 \mathrm{mg} / \mathrm{mL}$ hyaluronidase, and $1 \mathrm{mg} / \mathrm{mL}$ bovine serum albumin with acetate buffer (pH 3.9) and incubated them at $37^{\circ} \mathrm{C}$ for $20 \mathrm{~min}$. Next, a $5.0 \mathrm{mg} / \mathrm{mL}$ HA solution was employed to initiate the enzymatic reaction. The reaction was run at $37^{\circ} \mathrm{C}$ for $40 \mathrm{~min}$ and then stopped through the addition of alkaline borate. Here, hyaluronidase acted upon $\mathrm{HA}$ to release $\mathrm{N}$-acetylglucosamine. Because the release of $\mathrm{N}$-acetylglucosamine decreases in the presence of a hyaluronidase inhibitor, the changes were monitored by measuring the reaction mixture's absorbance at $600 \mathrm{~nm}$. As negative and positive controls, we used a blank test and tannic acid $(0.066,0.125,0.25$, and $0.3 \mathrm{mg} / \mathrm{mL})$, respectively. Finally, the inhibition of hyaluronidase activity was computed as follows:

$$
\text { Inhibition }(\%)=\frac{(\mathrm{A}-\mathrm{B})-(\mathrm{C}-\mathrm{D})}{\mathrm{A}-\mathrm{B}} \times 100,
$$

where $\mathrm{A}, \mathrm{B}, \mathrm{C}$, and $\mathrm{D}$ denote the absorbance values for mixtures containing hyaluronidase alone, no sample or hyaluronidase (blank), both the sample and hyaluronidase, and the sample alone, respectively.

\subsection{Kinetic Properties of Rice Protein Hydrolysate}

The method used here is reported elsewhere [16]. In brief, we first assayed the dose-dependent relationship between our rice protein hydrolysate and hyaluronidase. We placed our hydrolysate solution $(40 \mu \mathrm{L} ; 0,0.5,1,2,5,10$, and $20 \mathrm{mg} / \mathrm{mL})$ in a 96-well plate and then added hyaluronidase solution ( $5 \mu \mathrm{L} ; 0.5,1,2,5$, and $10 \mathrm{mg} / \mathrm{mL})$; moreover, $5.0 \mathrm{mg} / \mathrm{mL}$ HA in acetate buffer (100 $\mu \mathrm{L}, \mathrm{pH} 5.35$ ) was the substrate. This was followed by kinetic studies, where we added our hydrolysate solution $(50 \mu \mathrm{L} ; 10,0.5,1,2,5$, and $10 \mathrm{mg} / \mathrm{mL})$ to a 96-well plate and then hyaluronidase solution $(5 \mu \mathrm{L}$; $1 \mathrm{mg} / \mathrm{mL}$ ) was added. Next, we constructed a Lineweaver-Burk plot using the inverse of the substrate concentration $[S]$ and the reaction rate $V$ :

$$
\frac{1}{V}=\frac{K_{m}}{V_{\max }} \times \frac{1}{[\mathrm{~S}]}+\frac{1}{V_{\max }} .
$$

Here, the maximum velocity and the Michaelis constant are denoted $V_{\max }$ and $K_{m}$, respectively. In this double reciprocal plot, the linear regression line can be drawn and used for $K_{m}$ and $V_{\max }$ calculation because its $x$ intercept, $y$ intercept, and slope are $-1 / K_{m}, 1 / V_{\max }$, and $K_{m} / V_{\max }$, respectively. In addition, 
this plot can be applied for understanding if an inhibitor's reaction mechanism is competitive, uncompetitive, or noncompetitive [17].

\section{Results}

\subsection{Molecular Weights and Amino Acid Profiles of Rice Protein Hydrolysate}

Among the rice proteins, the prolamin, glutelin, globulin, and albumin have molecular weights of 7-13, 8-29, 13-60, and 7-135 kDa, respectively [18]. As shown by the results of tricine-SDS-PAGE (Figure 2), our rice protein hydrolysate's molecular weights were 5-63 kDa-corroborating the results for the same fractions in another study [19]. Moreover, a study [20] reported rice bran protein hydrolysate to have molecular weights of 6.5-66.2 kDa.

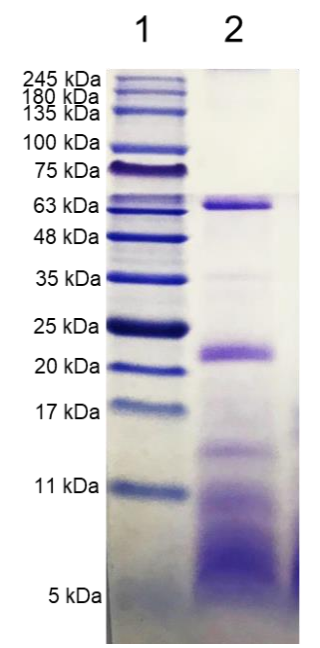

Figure 2. Tricine-SDS-PAGE results: (line 1) molecular-weight marker and (line 2) rice protein hydrolysate.

Table 1 presents the rice protein hydrolysate's amino acid profile: total amino acid content approximately $2960 \mathrm{mg}$ per $100 \mathrm{~g}$ of rice protein hydrolysate $(893 \mathrm{mg}$ of EAAs and $591 \mathrm{mg}$ of branched-chain amino acids).

Table 1. Rice protein hydrolysate's amino acid profile.

\begin{tabular}{cc}
\hline Amino Acid Profiles & Content in Rice Protein Hydrolysate $\mathbf{( m g / 1 0 0 ~ g ) ~}{ }^{\text {\# }}$ \\
\hline Alanine & 193 \\
Arginine & 248 \\
Aspartic acid & 308 \\
Cystine & 52 \\
Glutamic acid & 532 \\
Glycine & 161 \\
Histidine & 77 \\
Isoleucine & 113 \\
Leucine & 226 \\
Lysine & 135 \\
Methionine & 13 \\
Phenylalanine & 148 \\
Proline & 134 \\
Serine & 156 \\
Threonine & 116 \\
Tryptophan & - \\
Tyrosine & 167 \\
Valine & 180 \\
\hline Total amino acids (TAA) & 2960 \\
Essential amino acids (EAA) & 893 \\
Branched-chain amino acids (BCAA) & 519 \\
\hline
\end{tabular}

\# All values are expressed as means of duplicates. 


\subsection{Hyaluronidase Inhibition Ability of Rice Protein Hydrolysate}

We used tannic acid as a positive control. As Figure 3a illustrates, hyaluronidase activity inhibition increased as the added amount of tannic acid was increased, with the half maximal inhibitory concentration (IC50) being $0.14 \mathrm{mg} / \mathrm{mL}$ - close to the IC50 of $71.1 \mathrm{mM}(0.121 \mathrm{mg} / \mathrm{mL})$ reported by Nishida et al. [21]. Figure $3 \mathrm{~b}$ illustrates the inhibition of hyaluronidase activity using the rice protein hydrolysate solution as an inhibitor. The rice protein hydrolysate inhibition of hyaluronidase activity was dose dependent. Moreover, the line of linear regression had a slope and $y$ intercept of 4.0073 and 13.788, respectively. Accordingly, we determined the IC50 of our rice protein hydrolysate solution to be $7.61 \mathrm{mg} / \mathrm{mL}$. Aguilar-Toalá et al. [22] also concluded that bioactive peptides from milk fermented using specific strains of Lactobacillus plantarum could inhibit hyaluronidase.

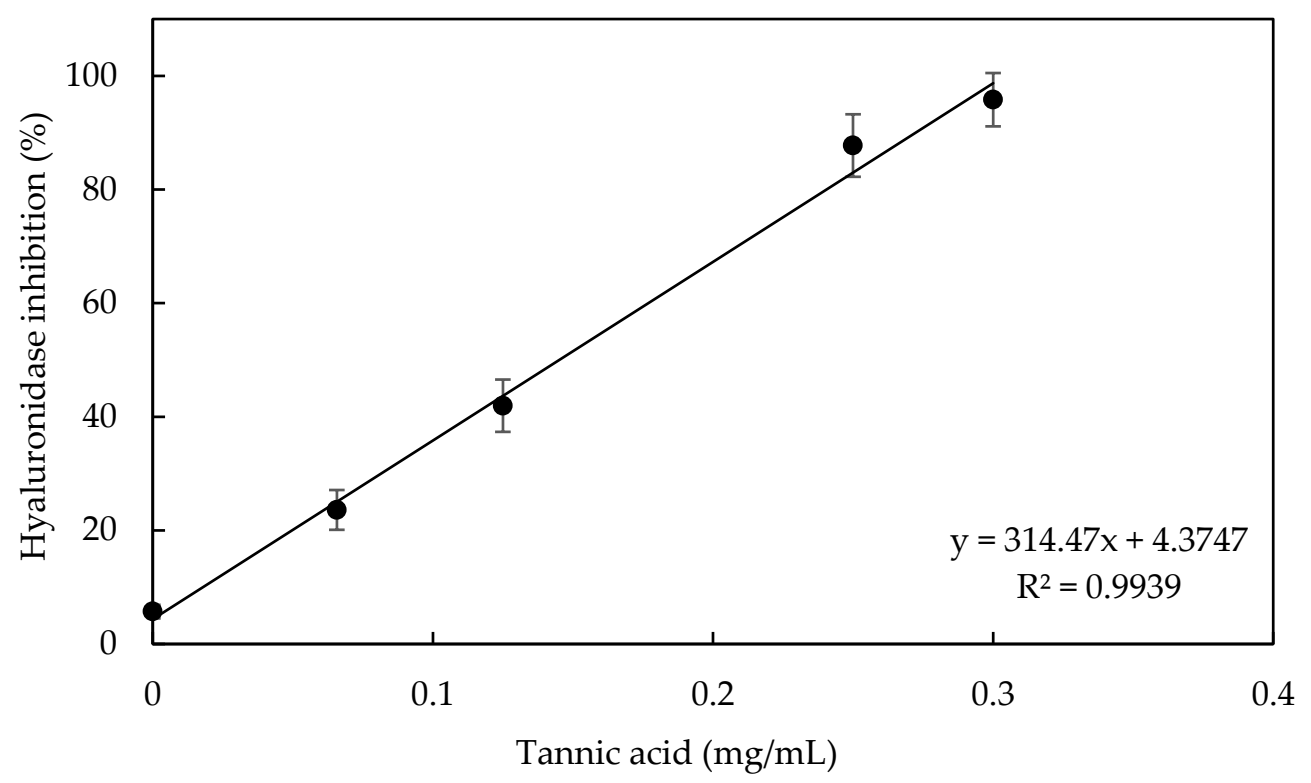

(a)

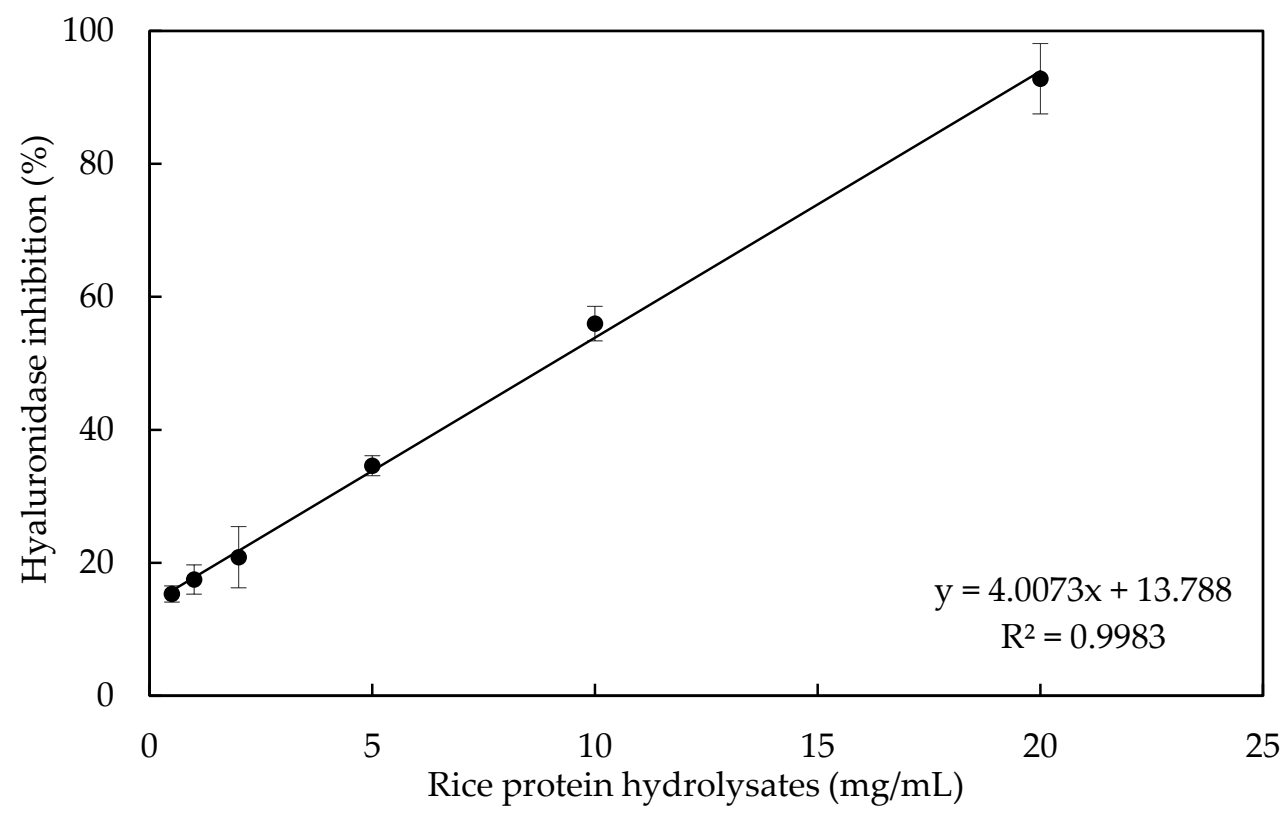

(b)

Figure 3. Hyaluronidase activity inhibition by different dilutions of (a) tannic acid $(\mathrm{mg} / \mathrm{mL})$ and $(\mathbf{b})$ rice protein hydrolysate $(\mathrm{mg} / \mathrm{mL})$. 
In general, plant-derived peptides, with low molecular weights and various biological functions, are regarded as healthy and safe. These peptides are absorbed easily and therefore are bioavailable in human body. Rice has nutritional, hypoallergenic, and health-promoting characteristics, all of which are retained by rice starch byproduct-derived peptides [23]. Although the rice protein hydrolysate does not have inhibitory activity higher than that of tannic acid, it is generally a natural ingredient safely usable in cosmetics [24].

\subsection{Hyaluronidase Inhibitory Activity Kinetics}

Our rice protein hydrolysate has the ability to inhibit hyaluronidase activity and degradation of HA. As illustrated in Figure 4, under the condition of $5 \mathrm{mg} / \mathrm{mL} \mathrm{HA}$ as the substrate, the hyaluronidase activity increased with the hyaluronidase concentration. The relationship of hyaluronidase activity with its concentration was linear, and the hyaluronidase activity decreased with the addition of the rice protein hydrolysate solution.

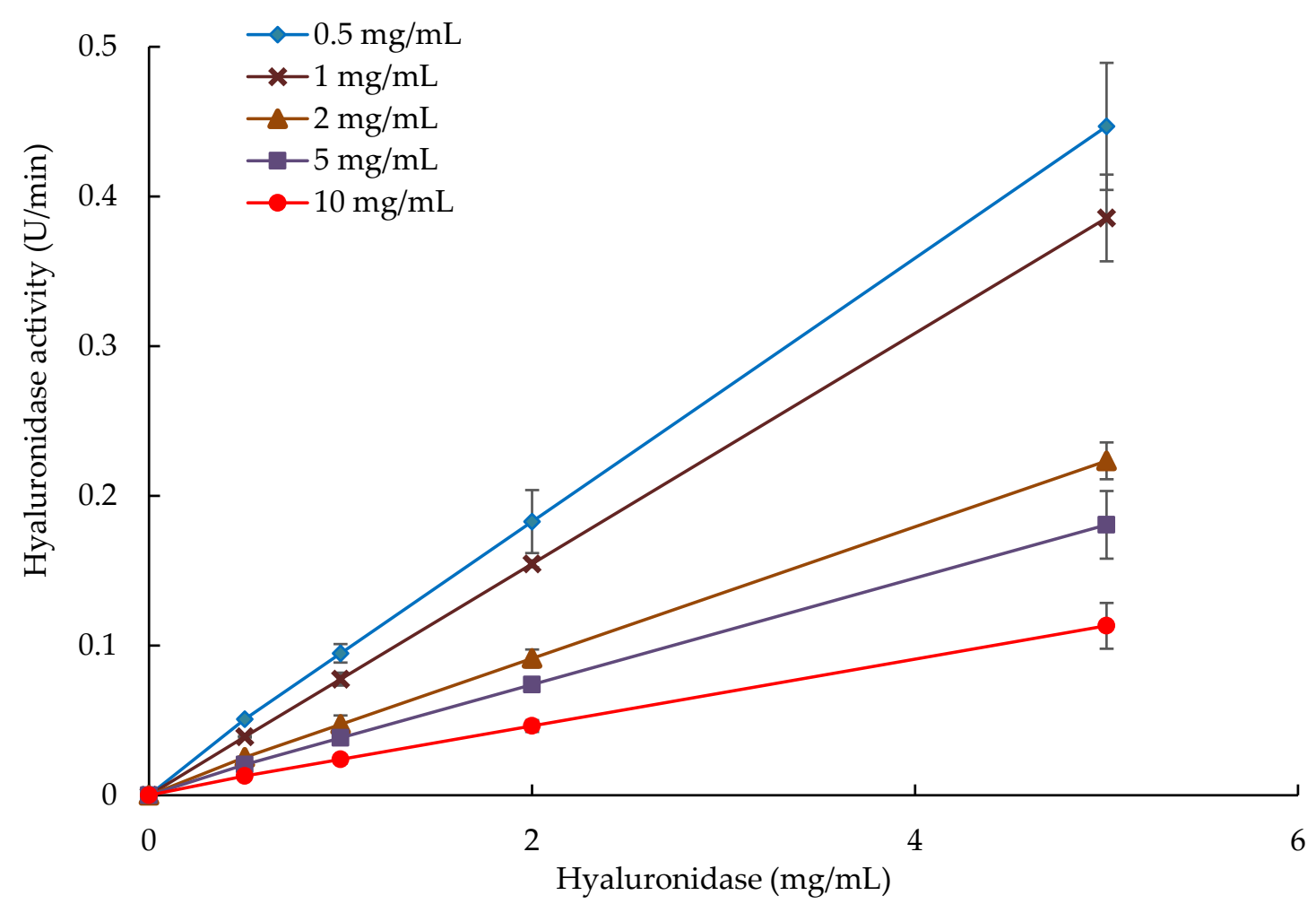

Figure 4. Effects of rice protein hydrolysate on the hyaluronidase activity with $5 \mathrm{mg} / \mathrm{mL} \mathrm{HA}$ as a substrate.

Next, we investigated the mechanism of hyaluronidase activity inhibition with HA as the substrate by constructing a Lineweaver-Burk double reciprocal plot for the relationship of the inverse of the reaction rate with that of HA concentration (Figure 5), where the concentration of the rice protein hydrolysate solution is a parameter. The results revealed that the five curves with different concentrations of the rice protein hydrolysate shared the same $y$ intercept $1 / V_{\max }$, indicating $V_{\max }=0.096 \mathrm{mM}$ for all cases. Moreover, $-1 / K_{m}$, the $x$ intercept, increased as the rice protein hydrolysate concentration was increased, revealing that $K_{m}$ increased with the inhibitors of rice protein hydrolysates. 


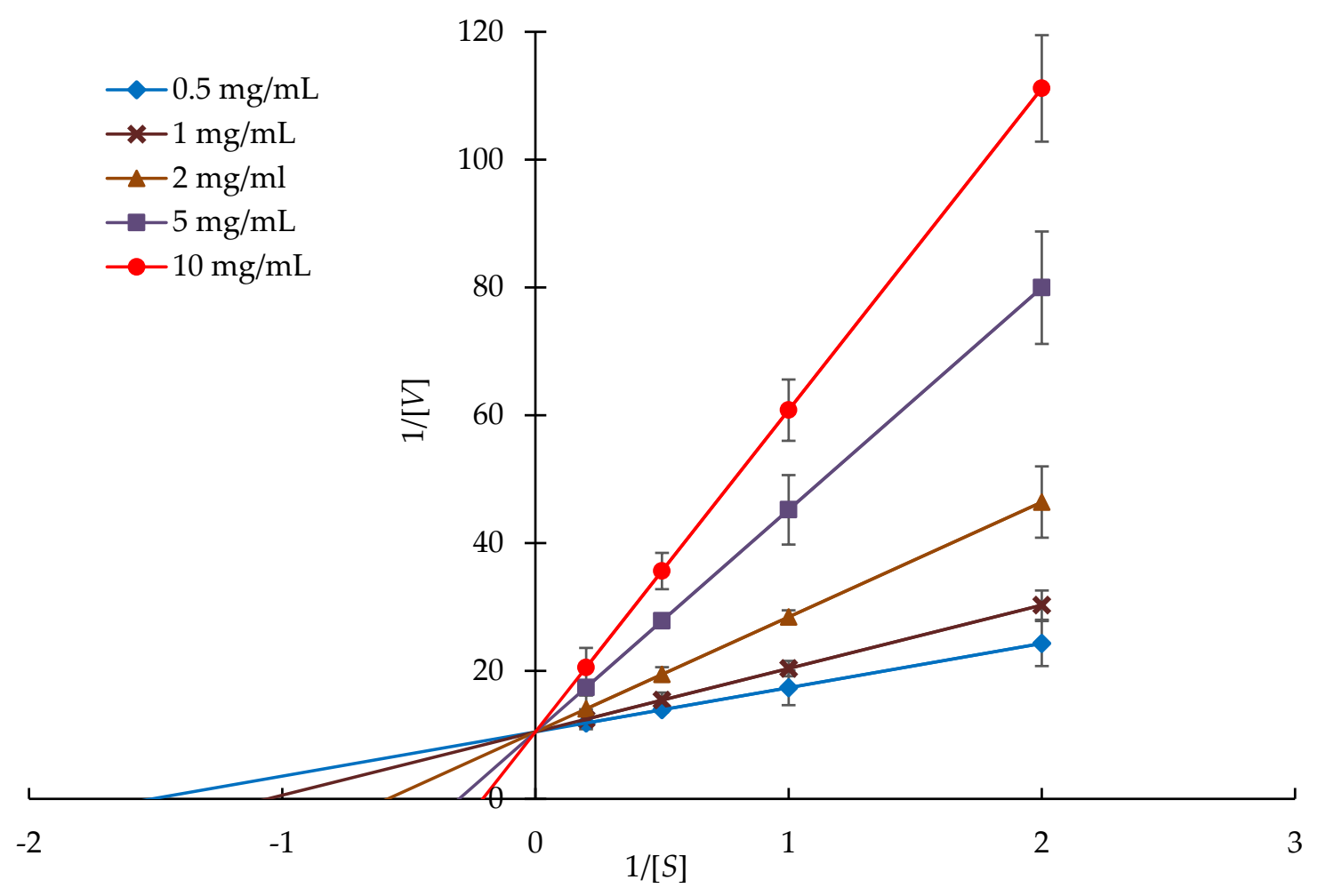

Figure 5. Lineweaver-Burk double reciprocal plot for rice protein hydrolysate concentration as a parameter ([V]: absorbance change rate, $\Delta \mathrm{OD}_{600} / \mathrm{min}$, and [S]: HA concentration).

Our rice protein hydrolysate solution thus can inhibit hyaluronidase activity effectively. Under this condition, the rice protein hydrolysate bound with hyaluronidase had an effect on the HA binding. Therefore, HA and rice protein hydrolysates both bound to the hyaluronidase. According to Figure 5, our rice protein hydrolysate's inhibition mechanism was competitive. A previous study [25] reported tannic acid to have a similar effect; however, chia seed peptides were noted to have a mixed inhibition pattern, where seven peptides (namely KKKRVYV, GFEWITF, GDAHWVY, GDAHWTY, GDAHWAY, DQNPRSF, and APHWYTN) were identified in the fraction [26]. Chen et al. [27] reported that rice protein hydrolysates' unique Val-Asn-Pro (VNP) and Val-Trp-Pro (VWP) characteristics enable their application in antihypertensive functional foods and drugs. In the rice tripeptides, the presence of proline may contribute to high angiotensin-converting enzyme (ACE) inhibitory activity. VNP and VWP are competitive inhibitors, and therefore their powerful ACE inhibition may be caused by reduction in ACE's capacity for substrate binding.

In the past 10 years, the research on peptides and protein from cereals and with multiple biological activities has rapidly increased. In 2018, Huang et al. [28] indicated proso millet to be a potential tyrosinase inhibitor and antioxidant; the authors also indicated its possible cosmetic applications. Industrial rice byproducts can also be hydrolyzed by selected enzymes and microbial systems to produce functional supplements and additives that are antioxidant-peptide rich and applicable in new food formulations for humans [29,30]. Empirical and bioinformatics studies thus far have mainly provided in vitro data and limited clinical evidence to prove these biological activities. Peptides and hydrolysates are therefore reasonable for use as health and functional foods [31].

\section{Conclusions}

Because of the wide biochemical diversity of proteins composed of various amino acids, obtaining protein hydrolysates with multiple unique biological functions is possible. We conclude that our rice protein hydrolysate effectively inhibits hyaluronidase activity, with an IC50 of $7.61 \mathrm{mg} / \mathrm{mL}$ and a 
competitive inhibitory mechanism. Here, an amplified enzymatic digestion process was established using food-grade proteolytic enzymes, and no solvents or chemicals were used. The current results provide a rationale for the direct development of peptides from industrial rice byproducts and may aid in developing cosmeceuticals that help manage diseases related to elevated hyaluronidase activity.

Author Contributions: Conceptualization: Y.-S.L.; methodology: H.-J.C., F.-J.D. and S.-L.F.; formal analysis: F.-J.D., Y.-S.L., and C.-S.C.; data curation: H.-J.C., F.-J.D., S.-L.F., and Y.-C.H.; writing-original draft preparation: F.-J.D., S.-L.F., and Y.-C.H.; and writing-review and editing: C.-F.C., Y.-S.L., and C.-S.C. All authors have read and agreed to the published version of the manuscript.

Funding: This research was funded by the Ministry of Science and Technology, grant number 109-2622-E-239-001-CC3.

Conflicts of Interest: The authors declare no conflict of interest.

\section{References}

1. Sloan, A.E. The top ten functional food trends. Food Technol. 2014, 54, 33-62.

2. Clemente, A. Enzymatic protein hydrolysates in human nutrition. Trends Food Sci. Technol. 2000, 11, $254-262$. [CrossRef]

3. Kannan, A.; Hettiarachchy, N.; Marshall, M. Food Proteins and Peptides as Bioactive Agents. Food Proteins Pept. 2011, 5, 1-28. [CrossRef]

4. Adjonu, R.; Doran, G.; Torley, P.; Agboola, S. Screening of whey protein isolate hydrolysates for their dual functionality: Influence of heat pre-treatment and enzyme specificity. Food Chem. 2013, 136, 1435-1443. [CrossRef]

5. Korhonen, H.; Pihlanto, A. Bioactive peptides: Production and functionality. Int. Dairy J. 2006, 16, 945-960. [CrossRef]

6. Kamdem, J.P.; Tsopmo, A. Reactivity of peptides within the food matrix. J. Food Biochem. 2017, 43, e12489. [CrossRef]

7. Erdmann, K.; Cheung, B.W.Y.; Schröder, H. The possible roles of food-derived bioactive peptides in reducing the risk of cardiovascular disease. J. Nutr. Biochem. 2008, 19, 643-654. [CrossRef]

8. Tsopmo, A.; Romanowski, A.; Banda, L.; Lavoie, J.-C.; Jenssen, H.; Friel, J.K. Novel anti-oxidative peptides from enzymatic digestion of human milk. Food Chem. 2011, 126, 1138-1143. [CrossRef]

9. García, M.C.; Puchalska, P.; Esteve, C.; Marina, M. Vegetable foods: A cheap source of proteins and peptides with antihypertensive, antioxidant, and other less occurrence bioactivities. Talanta 2013, 106, 328-349. [CrossRef] [PubMed]

10. Thamnarathip, P.; Jangchud, K.; Nitisinprasert, S.; Vardhanabhuti, B. Identification of peptide molecular weight from rice bran protein hydrolysate with high antioxidant activity. J. Cereal Sci. 2016, 69, 329-335. [CrossRef]

11. Sahasrabudhe, A.; Deodhar, M. Anti-hyaluronidase, Anti-elastase Activity of Garcinia indica. Int. J. Bot. 2010, 6, 299-303. [CrossRef]

12. Satardekar, K.V.; Deodhar, M.A. Anti-ageing ability of Terminalia species with special reference to hyaluronidase, elastase inhibition and collagen synthesis in vitro. Int. J. Pharmacogn. Phytochem. Res. 2010, 23, 30-34.

13. Schägger, H. Tricine-SDS-PAGE. Nat. Protoc. 2006, 1, 16-22. [CrossRef] [PubMed]

14. Simpson, R.J.; Neuberger, M.R.; Liu, T.Y. Complete amino acid analysis of proteins from a single hydrolysate. J. Biol. Chem. 1976, 251, 1936-1940. [PubMed]

15. Chompoo, J.; Upadhyay, A.; Fukuta, M.; Tawata, S. Effect of Alpinia zerumbet components on antioxidant and skin diseases-related enzymes. BMC Complement. Altern. Med. 2012, 12, 106. [CrossRef] [PubMed]

16. Lin, Y.-S.; Chen, H.-J.; Huang, J.-P.; Lee, P.-C.; Tsai, C.-R.; Hsu, T.-F.; Huang, W.-Y. Kinetics of tyrosinase inhibitory activity using Vitis vinifera leaf extracts. BioMed Res. Int. 2017, 2017, 5232680. [CrossRef] [PubMed]

17. Hemachandran, H.; Anantharaman, A.; Mohan, S.; Mohan, G.; Kumar, D.T.; Dey, D.; Kumar, D.; Dey, P.; Choudhury, A.; Doss, C.G.P.; et al. Unraveling the inhibition mechanism of cyanidin-3-sophoro- side on polyphenol oxidase and its effect on enzymatic browning of apples. Food Chem. 2017, 227, 102-110. [CrossRef]

18. Padhye, V.W.; Salunkhe, D.K. Extraction and characterization of rice proteins. Cereal Chem. 1979, 56, 389-393. 
19. Chanput, W.; Theerakulkait, C.; Nakai, S. Antioxidative properties of partially purified barley hordein, rice bran protein fractions and their hydrolysates. J. Cereal Sci. 2009, 49, 422-428. [CrossRef]

20. Tang, S.; Hettiarachchy, N.S.; Horax, R.; Eswaranandam, S. Physicochemical properties and functionality of rice-bran-protein hydrolysate prepared from heat-stabilized defatted rice bran with the aid of enzymes. J. Food Sci. 2003, 68, 152-157. [CrossRef]

21. Nishida, Y.; Sugahara, S.; Wada, K.; Toyohisa, D.; Tanaka, T.; Ono, M.; Yasuda, S. Inhibitory effects of the ethyl acetate extract from bulbs of Scilla scilloides on lipoxygenase and hyaluronidase activities. Pharm. Biol. 2014, 52, 1351-1357. [CrossRef] [PubMed]

22. Aguilar-Toalá, J.E.; Santiago-López, L.; Peres, C.M.; Peres, C.; Garcia, H.S.; Vallejo-Cordoba, B.; González-Córdova, A.F.; Hernández-Mendoza, A. Assessment of multifunctional activity of bioactive peptides derived from fermented milk by specific Lactobacillus plantarum strains. J. Dairy Sci. 2017, 100, 65-75. [CrossRef] [PubMed]

23. Zhang, J.; Zhang, H.; Wang, L.; Guo, X.; Wang, X.; Yao, H. Isolation and identification of antioxidative peptides from rice endosperm protein enzymatic hydrolysate by consecutive chromatography and MALDI-TOF/TOF MS/MS. Food Chem. 2010, 119, 226-234. [CrossRef]

24. Fernandes, F.; Ramalhosa, E.; Pires, P.; Verdial, J.; Valentão, P.; Andrade, P.; Bento, A.; Pereira, J.A. Vitis vinifera leaves towards bioactivity. Ind. Crop. Prod. 2013, 43, 434-440. [CrossRef]

25. Zhou, J.-R.; Kimura, S.; Nohara, T.; Yokomizo, K. Competitive Inhibition of Mammalian Hyaluronidase by Tomato Saponin, Esculeoside A. Nat. Prod. Commun. 2018, 13, 1461-1463. [CrossRef]

26. Aguilar-Toalá, J.E.; Liceaga, A.M. Identification of chia seed (Salvia hispanica L.) peptides with enzyme inhibition activity towards skin-aging enzymes. Amino Acids 2020, 52, 1149-1159. [CrossRef]

27. Chen, J.; Liu, S.; Ye, R.; Cai, G.; Ji, B.; Wu, Y. Angiotensin-I converting enzyme (ACE) inhibitory tripeptides from rice protein hydrolysate: Purification and characterization. J. Funct. Foods 2013, 5, 1684-1692. [CrossRef]

28. Huang, W.-Y.; Chen, H.-J.; Lin, C.-C.; Chen, C.-S.; Lin, Y.-S. Kinetics Investigation on Mushroom Tyrosinase Inhibition of Proso Millet. J. Chem. 2018, 2018, 1-5. [CrossRef]

29. Piu', L.D.; Tassoni, A.; Serrazanetti, D.I.; Ferri, M.; Babini, E.; Tagliazucchi, D.; Gianotti, A. Exploitation of starch industry liquid by-product to produce bioactive peptides from rice hydrolyzed proteins. Food Chem. 2014, 155, 199-206. [CrossRef]

30. Yan, Q.; Huang, L.-H.; Sun, Q.; Jiang, Z.; Wu, X. Isolation, identification and synthesis of four novel antioxidant peptides from rice residue protein hydrolyzed by multiple proteases. Food Chem. 2015, 179, 290-295. [CrossRef]

31. Li-Chan, E.C. Bioactive peptides and protein hydrolysates: Research trends and challenges for application as nutraceuticals and functional food ingredients. Curr. Opin. Food Sci. 2015, 1, 28-37. [CrossRef]

Publisher's Note: MDPI stays neutral with regard to jurisdictional claims in published maps and institutional affiliations.

(C) 2020 by the authors. Licensee MDPI, Basel, Switzerland. This article is an open access article distributed under the terms and conditions of the Creative Commons Attribution (CC BY) license (http://creativecommons.org/licenses/by/4.0/). 